\title{
ДЕЯКІ ПИТАННЯ АДМІНІСТРАТИВНО-ПРАВОВОГО РЕГУЛЮВАННЯ ОХОРОНИ ЗЕМЕЛЬ В УКРАЇНI
}

\author{
БАСС Вікторія Олександрівна - кандидат юридичних наук, доцент кафедри \\ поліцейського права Національної академії внутрішніх справ \\ УДК 349.2 \\ DOI:10.32782/NP.2020.2.6
}

На основе анализа действующего законодательства рассмотренъ некоторые вопросъ административно-правового регулирования охранъ земель в Украине. Доказано, что в процессе осуществления правового регулирования и охраны земель государство выполняет четьире основнъие функиии - регулируюшую, стимулируюшую, контрольную и карательную.

Ключевые слова: охрана земель; регулирования охрань земель; правовая охрана

\section{Актуальність теми}

Основний закон держави Україна говорить про те, що земля є основним національним багатством, що перебуває під особливою охороною держави. Право власності на землю гарантується. Це право набувається i реалізується громадянами, юридичними особами та державою тільки відповідно до закону [1]. Це положення Конституції України відображено і деталізовано у Земельному кодексі України, Законі України «Про охорону земель» [2] та інших актах земельного законодавства.

Визначення «регулювання» трактується як дія за значенням «регулювати», яка, у свою чергу, має кілька значень: перше - впорядковувати що-небудь, керувати чимось, підкоряючи його відповідним правилам, певній системі; друге - домагатися нормальної роботи машини, установки, механізму і т. ін. (забезпечуючи злагоджену взаємодію складових частин, деталей; зменшуючи або збільшуючи швидкість, величину і т. ін., до- сягати потрібної сили, належного ступеня вияву чого-небудь) [3, с. 1207]. Тобто регулювання - це дії, спрямовані на забезпечення нормальної роботи чогось (механізму, установки тощо) шляхом підкорення його певній системі (системі правил).

Що стосується поняття «правове регулювання», то необхідно відмітити, що людство завжди надавало і надає важливого значення соціальному регулюванню і впорядкуванню суспільних відносин. Неодноразово підкреслювалося, що в системі соціального регулювання важлива роль належить саме правовому, бо для кожного суб'єкта права система засобів і способів реалізації права є важливою гарантією захисту прав, свобод та законних інтересів [4, с. 17]. У свою чергу, істотні зміни у суспільних відносинах, у цілях і завданнях правового регулювання завжди супроводжуються відповідними перетвореннями структури системи права, що склалася (наприклад, з'являються нові чи зникають деякі правові галузі, інститути тощо) [5, с. 32].

у цілому, система права включає такі взаємозалежні підрозділи, як галузі, підгалузі, інститути, субінститути, і є безпосереднім результатом і вираженням властивого правовому регулюванню процесу нормативної спеціалізації. Це «складне системне ієрархічне утворення, пронизане процесами інтеграції й диференціації» [6, с. 295], автономне утворення, що включає такі галузі права, що характеризуються «не лише особливостями юридичних норм, а й специ- 
фікою правовідносин і навіть своєрідністю юридичного мислення» [7, с. 83].

\section{Стан дослідження даної теми}

Учені, які досліджували дану проблематику, зокрема: В. Авер'янов, О. Бевз, В. Бевзенко, 3. Білошкурська, I. Богатирьов, Н. Бондарчук, В. Галунько, Крістоф Конрад Гільген, Я. Герасименко, В. Данкевич, В. Даугуль, О. Дорош, О. Дрозд, Т. Дроздюк, О. Дуліна, В. Заросило, М. Ейдельберг, В. Єрмоленко, С. Іванова, I. Ігнатенко, І. Казакова, І. Килимник, Т. Кондратюк, Н. Красюк, В. Крижановська, П. Кулинич, Детлеф Кухар, А. Кучер, О. Літошенко, Улріке Майєр-Еверлог, В. Малий, А. Мартин, А. Мірошниченко, О. Мірошниченко, А. Місінкевич, В. Мунтян, О. Поклонська, В. Правдюк, А. Савченко, О. Сакаль, I. Сiряченко, О. Статівка, Н. Титова, А. Третяк, Д. Федчишин, А. Череучук, М. Шульга, Уте Шультхайс, В. Швець та інші, мали різні погляди та квінтесенції із вирішення правових питань адміністративно-правового регулювання охорони земель в Україні.

О6'єктом дослідження виступають суспільні відносини у сфері адміністративноправового регулювання охорони земель в Україні.

\section{Виклад основного матеріалу}

Охорона земель - це система правових, організаційних, економічних, технологічних та інших заходів, спрямованих на раціональне використання земель, запобігання необгрунтованому вилученню земель сільськогосподарського призначення для несільськогосподарських потреб, захист від шкідливого антропогенного впливу, відтворення і підвищення родючості грунтів, підвищення продуктивності земель лісового фонду, забезпечення особливого режиму використання земель природоохоронного, оздоровчого, рекреаційного та історикокультурного призначення [2].

Адміністративно-правове регулювання охорони земель є надзвичайно важливим чинником забезпечення продовольчої та екологічної безпеки країни. Тому важливу роль у здійсненні завдань правової охорони земель відіграє держава шляхом виконання ряду своїх функцій.

У процесі здійснення правової охорони земель держава виконує чотири основні функції - регулюючу, стимулюючу, контрольну та каральну. Регулююча функція правової охорони земель зводиться до встановлення правил раціонального використання земельних ресурсів. Такі правила можуть встановлюватися, наприклад, у формі обов'язків власників і користувачів земельних ділянок щодо їх раціонального використання, нормативів допустимої експлуатації земель, нормативів їх якісного стану та допустимого антропогенного навантаження на земельні ресурси. Стимулююча функція правової охорони земель полягає в запровадженні економічних стимулів раціонального використання та охорони земельних ресурсів, які передбачені, зокрема, ст. 205 Земельного Кодексу України. Економічне стимулювання раціонального використання та охорони земель включає: а) надання податкових і кредитних пільг громадянам та юридичним особам, які здійснюють за власні кошти заходи, передбачені загальнодержавними та регіональними програмами використання і охорони земель;6 ) виділення коштів державного або місцевого бюджету громадянам та юридичним особам для відновлення попереднього стану земель, порушених не з їх вини; в) звільнення від плати за земельні ділянки, що перебувають у стадії сільськогосподарського освоєння або поліпшення їх стану згідно 3 державними та регіональними програмами; г) компенсацію 3 бюджетних коштів зниження доходу власників землі та землекористувачів внаслідок тимчасової консервації деградованих та малопродуктивних земель, що стали такими не з їх вини [8].

Контрольна функція правової охорони земель зводиться до здійснення відповідними органами державної влади та місцевого самоврядування державного контролю за використанням та охороною земель. Каральна функція правової охорони земель виявляється у встановленні санкцій за порушення правил раціонального використання і охорони земель та їх застосуванні до порушників земельного законодавства. Такі 
санкції застосовують суди, а також державні інспектори $з$ контролю за використанням і охороною земель та деякі інші посадові особи.

Важливим напрямом політики щодо державного регулювання охорони земель є стандартизація і нормування у галузі використання земель, які здійснюються шляхом прийняття нормативів і стандартів. Вони визначають вимоги щодо якості земель, допустимого антропогенного навантаження на грунти та окремі території, а також щодо допустимого сільськогосподарського освоєння земельного фонду країни. В Україні застосовуються, зокрема, нормативи: оптимального співвідношення земельних угідь; якісного стану грунтів; гранично допустимого забруднення грунтів; деградації земель та грунтів.

Верховною Радою України прийнято низку законів. Серед них - про землеустрій, про оцінку земель, про охорону земель, про державний контроль за використанням та охороною земель, про особисте селянське господарство, нова редакція закону про оренду землі, про порядок виділення в натурі (на місцевості) земельних ділянок власникам земельних часток (паїв), про іпотеку, про державну реєстрацію речових прав на нерухоме майно та їх обмежень, про розмежування земель державної та комунальної власності.

Закон України «Про внесення змін до деяких законодавчих актів України щодо умов обігу земель сільськогосподарського призначення», який набирає чинності 31 липня 2021 року (крім пункту 2, який набирає чинності з дня опублікування Закону)

Закон визначає, що «власники та користувачі земельних ділянок усіх форм власності, розташованих у масиві земель сільськогосподарського призначення, зобов'язані надавати право сервітуту для забезпечення проходу (проїзду) іншим власникам та користувачам земельних ділянок до належної їм на відповідному праві земельної ділянки», а набуття права власності на земельні ділянки сільськогосподарського призначення можливе лише: а) громадянами України; б) юридичними особами України, створеними і зареєстрованими за законодавством
України, учасниками (акціонерами, членами) якими є лише громадяни України та/ або держава, та/або територіальні громади;в) територіальними громадами; г) державою.

Право власності на земельні ділянки сільськогосподарського призначення може також набуватися банками лише в порядку звернення стягнення на них як на предмет застави. Такі земельні ділянки мають бути відчужені банками на земельних торгах протягом двох років 3 дня набуття права власності.

Іноземцям, особам без громадянства та юридичним особам заборонено набувати частки у статутному (складеному) капіталі, акції, паї, членство у юридичних особах (крім як у статутному (складеному) капіталі банків), які є власниками земель сільськогосподарського призначення. Цей абзац втрачає чинність за умови та $з$ дня схвалення на референдумі рішення, визначеного абзацом восьмим цієї частини.

Набуття права власності на земельні ділянки сільськогосподарського призначення юридичними особами, створеними і зареєстрованими за законодавством України, учасниками (засновниками) або кінцевими бенефіціарними власниками яких є особи, які не є громадянами України, може здійснюватися $з$ дня та за умови схвалення такого рішення на референдумі.

За будь-яких умов, у тому числі у разі схвалення на референдумі рішення, визначеного абзацом восьмим цієї частини, забороняється набуття права власності на земельні ділянки сільськогосподарського призначення: 1) юридичними особами, учасниками (акціонерами, членами) або кінцевими бенефіціарними власниками яких є особи, які не є громадянами України, - на земельні ділянки сільськогосподарського призначення державної і комунальної власності, земельні ділянки сільськогосподарського призначення, виділені в натурі (на місцевості) власникам земельних часток (паїв), які розташовані ближче 50 кілометрів від державного кордону України (крім державного кордону України, який проходить по морю); 2) юридичними особами, учасниками (акціонерами, членами) або кінцевими бенефіці- 
арними власниками яких є громадяни держави, визнаної Україною державою-агресором або державою-окупантом; 3) особами, які належать або належали до терористичних організацій; 4) юридичними особами, учасниками (акціонерами, членами) або кінцевими бенефіціарними власниками яких є іноземні держави; 5) юридичними особами, у яких неможливо встановити кінцевого бенефіціарного власника; 6) юридичними особами, кінцеві бенефіціарні власники яких зареєстровані в офшорних зонах, віднесених до переліку офшорних зон, затвердженого Кабінетом Міністрів України; 7) фізичними та юридичними особами, стосовно яких застосовано спеціальні економічні та інші обмежувальні заходи (санкції) відповідно до Закону України «Про санкції» у вигляді заборони на укладення правочинів з набуття у власність земельних ділянок, а також пов'язаними з ними особами; 8) юридичними особами, створеними за законодавством України, що перебувають під контролем фізичних та юридичних осіб, зареєстрованих у державах, включених Міжнародною групою $з$ протидії відмиванню брудних грошей (FATF) до списку держав, що не співпрацюють у сфері протидії відмиванню доходів, одержаних злочинним шляхом.

Укладення цивільно-правових угод, що передбачають перехід права власності на земельні ділянки, а також набуття права власності на земельні ділянки за такими угодами здійснюються відповідно до Цивільного кодексу України з урахуванням вимог Кодекcy.

Купівля-продаж земельної ділянки здійснюється 3 дотриманням переважного права на іiі придбання. Переважне право на придбання земельної ділянки може бути передано його суб'єктом іншій особі, про що такий суб'єкт має письмово повідомити власника земельної ділянки.

Законом забороняються відчуження земельних часток (паїв), земельних ділянок сільськогосподарського призначення державної і комунальної власності, відчуження та зміна цільового призначення земельних ділянок сільськогосподарського призначення приватної власності, виділених у натурі (на місцевості) власникам земельних часток (паїв), розташованих на тимчасово окупованих територіях у Донецькій та Ауганській областях, Автономної Республіки Крим та міста Севастополя, крім передачі їх у спадщину. Угоди (у тому числі довіреності), укладені під час дії заборони на купівлю-продаж або відчуження в інший спосіб земельних ділянок та земельних часток (паїв), визначених цим пунктом, у частині їх купівлі-продажу та відчуження в інший спосіб, а так само в частині передачі прав на відчуження цих земельних ділянок та земельних часток (паїв) на майбутнє, є недійсними з моменту їх укладення (посвідчення) [9].

\section{Висновки}

Виходячи 3 вище викладеного, можна констатувати, що адміністративно-правове регулювання питань, пов'язаних із землею, буде вирішене вже найближчим часом.

Так, 31 липня 2021 року отримають право купувати землю (аграрного призначення) лише громадяни України як фізичні особи. Але один українець має право володіти одночасно не більше ніж ста гектарами. Втім, тут не враховується та земля, якою громадянин володів до набуття чинності законом.

31 січня 2024 року купувати сільськогосподарську землю матимуть право як прості українці, так і юридичні особи. Aле за умови, що серед їхніх кінцевих власників 6 лише громадяни України, українські територіальні громади або держава. Збільшується і кількість землі, якою може володіти одна людина: до 10 тисяч гектарів.

Якщо ідеться про юридичну особу, то площа землі в її власності «не може перевищувати загальної площі земельних ділянок сільськогосподарського призначення, які можуть перебувати у власності всіх її учасників, але не більше від десяти тисяч гектарів».

Якщо в людини, крім власних земельних ділянок, є частка в компанії, яка володіє якимись аграрними угіддями, то ця людина вважається власником землі компанії: вона володіє стількома відсотками землі, скільки відсотків має в статутному капіталі цієї юридичної особи.

У разі схвалення на референдумі землю зможуть купувати іноземці. Зокрема, купуватимуть землю також юридичні особи, се- 


\section{Адміністративне право}

\section{АНОТАЦІЯ}

На основі аналізу чинного законодавства розглянуто деякі питання адміністративноправового регулювання охорони земель в Украйні. Доведено, що у процесі здійснення правового регулювання та охорони земель держава виконує чотири основні функиї - регулюючу, стимулюючу, контрольну та каральну.

Ключові слова: охорона земель; регулювання охорони земель; правова охорона.

ред засновників/бенефіціарів яких є іноземні громадяни. Також іноземці й особи без громадянства зможуть набувати частку або членство в юридичних особах, які вже мають землі аграрного призначення.

Також володіти землею аграрного призначення можуть:

- держава;

· територіальні громади;

$$
\text { - банки. }
$$

На останні не поширюється вимога «не більше ніж 100 га (з 2024 року - 10 тисяч га) в одні руки». Але банки мають право володіти аграрною землею лише за умови, що стягнули їі як заставу за кредитом. Причому володіти тимчасово: банкові дається два роки на те, щоб продати заставну землю.

Право українців давати землю в заставу і право банків на землю - це одна з найважливіших норм для кращого кредитування аграріїв, визнають в Українському клубі аграрного бізнесу.

\section{Література}

1. Конституція України: прийнята на п’ятій сесії Верховної Ради України від 28 червня 1996 року//[Електронний peсурс] - Режим доступу: https://zakon. rada.gov.ua/laws/show $/ 254 \%$ D0\%BA/96\%D0\%B2\%D1\%80\#Text.

2. Про охорону земель: Закон України від 19 червня 2003 року № 962-IV//[Електро-

\section{SUMMARY}

Based on the analysis of the current legislation, some issues of administrative and legal regulation of land protection in Ukraine are considered. It is proved that in the process of implementing legal regulation and land protection, the state performs four main functions - regulatory, stimulating, controlling and punitive.

Keywords: land protection; land protection regulation; legal protection.

нний ресурс] - Режим доступу: https://zakon. rada.gov.ua/laws/show/962-15\#Text.

3. Великий тлумачний словник сучасної української мови: 250000 / уклад. та голов. ред. В. Т. Бусел. К.; Ірпінь: Перун, 2005. VIII. 1728 c.

4. Оніщенко Н. М. Гармонізація правової системи України як чинник забезпечення прав, свобод і законних інтересів громадян / Університетські наукові записки. 2008. № 4 (28). С. 17-24.

5. Добробог А. М. Система права: теоретико-правовий дискурс / Науковий вісник Ужгородського національного університету. 2013. Серія Право. Випуск 21. Частина II. Том 1. С. 30-32.

6. Теория государства и права: курс лекций / под ред. Н. И. Матузова,А. В. Малько. 2-е изд., перераб. и доп. М., 1995. С. 295.

7. Тиунова $\mathcal{\Lambda}$. Б. Системные связи правовой действительности / $\mathcal{A}$. Б. Тиунова. СПб, 1999. С. 83.

8. Земельний кодекс України від 25 жовтня 2001 року № 2768-III //[Електронний ресурс] - Режим доступу: https://zakon. rada.gov.ua/laws/show/2768-14\#Text.

9. Про внесення змін до деяких законодавчих актів України щодо умов обігу земель сільськогосподарського призначення: Закон України від 31 березня 2020 рокуN 552-IX //[Електронний ресурс] - Режим доступу: https://ips.ligazakon.net/document/ view/t200552? $\mathrm{an}=72$. 